\title{
Microbial and metabolic profile of achlorhydric stomach: comparison of pernicious anaemia and hypogammaglobulinaemia
}

\author{
SP BORRIELLO, PJ REED, JM DOLBY, FE BARCLAY, ADB WEBSTER* \\ From the Divisions of Communicable Diseases and Immunological Medicine, ${ }^{*}$ Clinical Research Centre, \\ Watford Road, Harrow, Middlesex
}

SUMMARY The microbial flora and some of its metabolites and enzymes in the stomach were compared in patients with achlorhydria, pernicious anaemia, and primary hypogammaglobulinaemia and in patients with dyspepsia with normal gastric acidity. Detailed analysis of the flora of the gastric juice and of the mucosa from the antrum, body, and fundus in six patients with hypogammaglobulinaemia (mean $\mathrm{pH} 8 \cdot 2$ ), seven patients with pernicious anaemia (mean $\mathrm{pH}$ $7 \cdot 3$ ), and five patients with dyspepsia (mean $\mathrm{pH} 1.9$ ) yielded 22 different genera of bacteria, mainly from the patients with achlorhydria, the most common being streptococci, micrococci, staphylococci, veillonella, and lactobacilli. A similar flora was found associated with the mucosa at all three sites. Various metabolites were also looked for. $\beta$ Glucoronidase and $C_{14}$ lipase were found in patients with hypogammaglobulinaemia but not in those with pernicious anaemia or dyspepsia. Volatile fatty acids were not found. Relatively high concentrations of ethanol were found in the patients with hypogammaglobulinaemia compared with those with pernicious anaemia $(p$ $=0.02)$. Similar concentrations of dimethylamine were found in all three groups, but the concentrations of trimethylamine were much higher in patients with pernicious anaemia and hypogammaglobulinaemia.

The high concentrations of some microbial enzymes and ethanol differentiated the group with hypogammaglobulinaemia from the rest, and these may bear some relation to the high incidence of gastric cancer in patients with hypogammaglobulinaemia.

Considerable interest in the microbial flora of the achlorhydric stomach, ${ }^{1-y}$ followed the suggestion that carcinogenic nitrosamines may be formed at near neutral $\mathrm{pH}$ by the bacterial reduction of dietary nitrates to nitrites, with subsequent $N$ nitrosation of secondary amines." This theory may explain the increased incidence of gastric cancer in patients with achlorhydria, especially those with pernicious anaemia or hypogammaglobulinaemia. Most of the work has been concentrated on analysis of the bacterial flora and nitrate and nitrite concentrations of gastric juice ${ }^{1-4}$; little attention has been paid to the microbial flora associated with the mucosa in different regions of the stomach. Possibly, metabolites produced at the mucosal surface are more important than those produced in the lumen. In addition, the presence of amines, cocarcinogens, or other possible

Accepted for publication 8 May 1985 markers of disease have rarely been looked for.

We performed a detailed analysis of the microbial flora of the gastric juice and gastric mucosal flora at three different sites in patients with achlorhydria and hypogammaglobulinaemia or pernicious anaemia. The findings were compared with those obtained in a group of subjects with low gastric $\mathrm{pH}$ values. The gross microbial findings are presented in brief elsewhere.' In addition, the juices were analysed for the presence of various enzymes, short chain fatty acids, amines, and alcohols. The aim of these later investigations was to identify and measure those amines that might affect the formation of nitrosamines and to determine whether there were other microbial metabolites present that could allow us to differentiate between the groups of patients.

\section{Material and methods}

Three groups of patients, described in detail else946 
where, ${ }^{1}$ were investigated. Six adult patients with primary hypogammaglobulinaemia of late onset, known to have pentagastrin fast achlorhydria, were studied. Five of these patients were receiving weekly replacement treatment with gammaglobulin. Only one patient had taken antibiotics (amoxycillin and flucloxacillin) within a week of the investigation. The second group comprised seven patients with typical pernicious anaemia responsive to vitamin $B_{12}$ who were also unable to produce stomach acid after an injection of pentagastrin. Both these groups underwent routine endoscopy as a screening procedure for early gastric carcinoma; they had given informed consent for the procedures outlined below. The third group comprised five patients who underwent endoscopy for dyspepsia but who were subsequently considered not to have significant disease.

\section{COLLECTION OF GASTRIC JUICE AND BIOPSY}

MATERIAL

Samples of gastric juice were collected at endoscopy as described previously' and stored frozen at $-30^{\circ} \mathrm{C}$ as a 1:10 dilution in glycerol broth for bacteriological analysis ${ }^{10}$ and neat for biochemical analysis. Biopsies from the antrum, body, and fundus obtained during this investigation were individually placed into $4.5 \mathrm{ml}$ volumes of glycerol broth, transferred to an anaerobe cabinet (Forma Scientific, Ohio) within 10 minutes of collection, washed three times with $5 \mathrm{ml}$ of a brain heart infusion broth: physiological saline mix $(1: 1)$, and then placed in a preweighed bijou containing $2 \mathrm{ml}$ glycerol broth. These were reweighed, the weight of the biopsy (about $10 \mathrm{mg}$ ) was determined, and they were then rapidly frozen and stored at $-30^{\circ} \mathrm{C}$.

\section{BACTERIOLOGICAL INVESTIGATIONS}

Biopsies and juice were thawed in the anaerobe cabinet. Tissue was homogenised with sterile glass grinders in the suspending fluid, and these and the juice diluted 10-fold over six steps in prereduced brain heart infusion (Oxoid) with added reducing agents and growth factors." Quantitative estimates were made according to the method of Miles and Misra. ${ }^{12}$ To detect small numbers a spread plate of $0.1 \mathrm{ml}$ of the lowest dilution was made. The following range of media were used: reinforced clostridial agar (Oxoid) with $7.5 \%$ horse blood for anaerobes; Columbia agar (Oxoid) with $5 \%$ horse blood for aerobes; selective media for bacteroides, veillonella and bifidobacteria, ${ }^{11}$ lactobacilli, ${ }^{13}$ streptococci ${ }^{14}$; and MacConkey medium (Oxoid) for enterobacteriaceae. For the specific isolation of clostridia treatment with ethanol was used to select for spores ${ }^{15}$ and the treated suspensions seeded on to a medium containing egg yolk. ${ }^{16}$
All agar media for the isolation of anaerobes were prereduced and after inoculation incubated in an atmosphere of $10 \%$ carbon dioxide, $10 \%$ hydrogen, and $80 \%$ nitrogen, at $37^{\circ} \mathrm{C}$ for five days in an incubator housed in an anaerobe cabinet. MacConkey agar medium was incubated at $37^{\circ} \mathrm{C}$ in air overnight. All other media were incubated at $37^{\circ} \mathrm{C}$ in candle jars for two days. Organisms were identified by standard criteria, including analysis of the volatile fatty acid end products of metabolism by gas-liquid chromatography. ${ }^{17}$ Triplicate mean counts were determined and the results recorded as the $\log _{10}$ number of organisms/ml or $\mathrm{g}$.

\section{GAS CHROMATOGRAPHIC ANALYSIS OF GASTRIC} JUICE

Undiluted samples were analysed on a Varian 3700 chromatograph with dual flame ionisation detectors. In all cases glass columns five feet long with an internal diameter of $2 \mathrm{~mm}$ were used. To detect amines the column was soaked overnight in $2 \mathrm{M}$ potassium hydroxide, dried without rinsing, packed (leaving a $7 \mathrm{~cm}$ gap at the top) with $4 \%$ Carbowax $20 \mathrm{M} / 0.8 \%$ potassium hydroxide coated on to Carbopak B (Supelco Inc, Chromatography Services, Carr Lane Industrial Estate, Hoylake, Wirral, Merseyside), and plugged at both ends with glass wool that had been soaked in potassium hydroxide. The column was conditioned by heating to $220^{\circ} \mathrm{C}$ overnight, then injecting $30 \times 10 \mu \mathrm{l}$ aliquots of distilled water at intervals of one minute before reducing the temperature. Working conditions were: injector $220^{\circ} \mathrm{C}$, detector $250^{\circ} \mathrm{C}$, column $70^{\circ} \mathrm{C}$ (for five minutes), rising at $7^{\circ} \mathrm{C} / \mathrm{min}$ to $135^{\circ} \mathrm{C}$ (for 20 minutes), carrier gas nitrogen $23 \mathrm{ml} / \mathrm{min}$, and attenuation $8 \times 10^{-12} / \mathrm{amps} / \mathrm{mv}$. Volumes of $0.1 \mu \mathrm{l}$ were coinjected on to the column with equal volumes of $0.2 \mathrm{M}$ potassium hydroxide. Standard solutions of dimethylamine $(10.8 \mu \mathrm{g} / \mathrm{ml})$, retention time 1.98 minutes, and trimethylamine $(18.5 \mu \mathrm{g} / \mathrm{ml})$, retention time 3.29 minutes, were also run and the amine content of the samples estimated by comparing peak heights with these external standards.

Ethanol was detected by use of Chromosorb 103 (Phase Separations Ltd, Deeside Industrial Estate, Queensferry, Clwyd). The column was washed with $10 \%$ hydrochloric acid and $2 \mathrm{M}$ sodium hydroxide before packing. Working conditions were: injector $110^{\circ} \mathrm{C}$, detector $180^{\circ} \mathrm{C}$, column $105^{\circ} \mathrm{C}$ (for five minutes), rising at $10^{\circ} \mathrm{C} / \mathrm{min}$ to $165^{\circ} \mathrm{C}$, carrier gas nitrogen $23 \mathrm{ml} / \mathrm{min}$, attenuation $32 \times 10^{-12} / \mathrm{amps} /$ mv. Volumes of $1 \mu \mathrm{l}$ were coinjected on to the column with an equal volume of $0.05 \mathrm{M}$ sodium hydroxide. The ethanol content of samples was estimated by comparing integrated peak areas with those of a standard solution of ethanol $(71 \mu \mathrm{g} / \mathrm{ml})$. 
Standard solutions of ethanol gave a linear response from $10 \mu \mathrm{g} / \mathrm{ml}$ to $1000 \mu \mathrm{g} / \mathrm{ml}$.

Volatile fatty acids were detected by use of Chromosorb 101 (Phase Separations Ltd) pretreated by the method of Barrett et al. ${ }^{18}$ The column was washed with $10 \%$ hydrochloric acid before packing. Working conditions were: injector $180^{\circ} \mathrm{C}$, detector $200^{\circ} \mathrm{C}$, column $170^{\circ} \mathrm{C}$, carrier gas nitrogen $23 \mathrm{ml} / \mathrm{min}$, and attenuation $4 \times 10^{-11} / \mathrm{amps} / \mathrm{mv}$. One $\mu$ l of sample was coinjected on to the column with an equal volume of $0.1 \%$ formic acid.

\section{MEASUREMENT OF GASTRIC JUICE pH}

Immediately after sampling the $\mathrm{pH}$ of the gastric juice was measured with a microglass electrode (Pye Unicam model 290) calibrated against standard buffers. In one of the patients with pernicious anaemia the $\mathrm{pH}$ was measured after storage.

\section{DETECTION OF GASTRIC JUICE ENZYMES}

The undiluted gastric juices were screened for the presence of acid and alkaline phosphatase, $\mathrm{C}_{4}$ esterase, $C_{8}$ esterase lipase, $C_{14}$ lipase, leucine, valine and cystine arylamidase, trypsin, chymotrypsin, phosphoamidase, $\alpha$ and $\beta$ galactosidase, $\beta$ glucuronidase, $\alpha$ and $\beta$ glucosidase, $N$ acetyl $\beta$ glucosaminidase, $\alpha$ mannosidase, and $\alpha$ fucosidase by use of the API Zym system (API Laboratory Products Ltd, Basingstoke, Hampshire) according to the manufacturer's instructions.
Statistical analysis The data were analysed by the method of Hill and Peto, ${ }^{19}$ which is suited to analyses of small numbers of results.

\section{Results}

PH VALUES OF GASTRIC JUICE

The $\mathrm{pH}$ of the gastric juice was alkaline in all six of the patients with hypogammaglobulinaemia, with a mean value of 8.2 (range 7.8 to 8.4 ). All of the patients with pernicious anaemia had achlorhydria with $\mathrm{pH}$ values close to neutral, with a mean value of $7 \cdot 3$ (range 6.8 to $7 \cdot 5$ ). The five patients with dyspepsia in the group for comparison had acid gastric juice of mean $\mathrm{pH} 1.9$ (range 1.3 to 3.4 ). The gastric $\mathrm{pH}$ values of the patients with hypogammaglobulinaemia were significantly higher than those of the patients with pernicious anaemia $(p=0.001)$.

\section{BACTERIAL FLORA}

A great variety of different micro-organisms were isolated from the juices and mucosal biopsies of the stomachs of the patients with achlorhydria (Table 1). In general, the most commonly found bacteria were veillonella, lactobacilli, and facultative Gram positive cocci such as streptococci, micrococci, and staphylococci (Table 1). Klebsiella were found in the stomachs of five of the seven patients with pernicious anaemia, but in only one with hypogammaglobulinaemia (Table 1). Escherichia coli was not

Table 1 Micro-organisms isolated from all sites in stomach (figures are numbers of patients)

\begin{tabular}{|c|c|c|c|}
\hline Micro-organism & $\begin{array}{l}\text { Patients with hypogammaglobulinaemia } \\
(n=6)\end{array}$ & $\begin{array}{l}\text { Patients with pernicious anaemia } \\
(n=7)\end{array}$ & $\begin{array}{l}\text { Group with low pH } \\
(n=5)\end{array}$ \\
\hline \multicolumn{4}{|l|}{ Gram positive cocci: } \\
\hline Aerobic streptococci & 6 & 7 & 3 \\
\hline Anaerobic streptococci & 1 & 1 & 0 \\
\hline Micrococci & 6 & 6 & 2 \\
\hline Staphylococci & 6 & 5 & 5 \\
\hline \multicolumn{4}{|l|}{ Gram negative cocci: } \\
\hline Neisseria & 2 & 1 & 0 \\
\hline Veillonella & 6 & 7 & 1 \\
\hline \multicolumn{4}{|l|}{ Gram positive rods: } \\
\hline Lactobacilli & 5 & 6 & 2 \\
\hline Diptheroides & 2 & 4 & 1 \\
\hline Bifidobacteria & 4 & 6 & 1 \\
\hline Eubacteria & 1 & 1 & 0 \\
\hline Clostridia & $\mathbf{0}$ & 1 & 0 \\
\hline Bacilli & 0 & 1 & 0 \\
\hline Propionibacteria & 1 & 2 & 0 \\
\hline \multicolumn{4}{|l|}{ Gram negative rods: } \\
\hline Klebsiella & 1 & 5 & 0 \\
\hline Pseudomonas & 1 & 3 & 0 \\
\hline Haemophilus & 1 & 1 & 0 \\
\hline Bacteroides & 3 & 0 & 0 \\
\hline Fusobacteria & 0 & 0 & 0 \\
\hline Citrobacter & 0 & 1 & 0 \\
\hline Alcaligenes & 0 & 0 & 0 \\
\hline Proteus & 1 & 0 & 0 \\
\hline Hafnia & 1 & 0 & 0 \\
\hline Yeasts & 0 & 2 & 0 \\
\hline
\end{tabular}


Table 2 Micro-organisms isolated from gastric juice (figures are numbers of patients and mean $\log _{10}$ No of organisms $/$ ml juice)

\begin{tabular}{llll}
\hline Micro-organism & $\begin{array}{l}\text { Patients with hypogammaglobulinaemia } \\
(n=6)\end{array}$ & $\begin{array}{l}\text { Patients with pernicious anaemia } \\
(n=7)\end{array}$ & $\begin{array}{l}\text { Group with low pH } \\
(n=5)\end{array}$ \\
\hline Gram positive cocci: & & & \\
Aerobic streptococci & $5(6 \cdot 6)$ & $7(7 \cdot 1)$ & $2(3 \cdot 3)$ \\
Anaerobic streptococci & $1(4 \cdot 7)$ & $1(6 \cdot 6)$ & 0 \\
Micrococci & $2(6 \cdot 3)$ & $5(5 \cdot 8)$ & $1(2 \cdot 6)$ \\
Staphylococci & $5(4 \cdot 3)$ & $3(5 \cdot 0)$ & $3(3 \cdot 2)$ \\
Gram negative cocci: & $1(5 \cdot 0)$ & 0 & 0 \\
Neisseria & $3(6 \cdot 1)$ & $6(4 \cdot 7)$ & $1(2 \cdot 0)$ \\
Veillonella & $3(3 \cdot 8)$ & $5(4 \cdot 6)$ & $1(3 \cdot 0)$ \\
Gram positive rods: & $1(6 \cdot 0)$ & $2(6 \cdot 5)$ & 0 \\
Lactobacilli & $1(7 \cdot 3)$ & $6(5 \cdot 9)$ & 0 \\
Diptheroides & 0 & 0 & 0 \\
Bifidobacteria & 0 & $1(3 \cdot 0)$ & 0 \\
Clostridia & 0 & $2(5 \cdot 2)$ & 0 \\
Bacilli & $1(4 \cdot 1)$ & $5(4 \cdot 2)$ & \\
Propionibacteria & $1(6 \cdot 0)$ & $3(4 \cdot 2)$ & 0 \\
Gram negative rods: & $1(8 \cdot 0)$ & 0 & 0 \\
Klebsiella & $1(4 \cdot 7)$ & 0 & 0 \\
Pseudomonas & 0 & 0 & 0 \\
Haemophilus & 0 & $1(4 \cdot 0)$ & 0 \\
Bacteroides & 0 & 0 & 0 \\
Fusobacteria & $1(3 \cdot 0)$ & 0 & 0 \\
Citrobacter & $1(4 \cdot 4)$ & 0 & 0 \\
Alcaligenes & 0 & $2(3 \cdot 2)$ & 0 \\
Proteus & & & 0 \\
Hafnia & & & \\
Yeasts & & & \\
\hline
\end{tabular}

isolated from any of the groups. Far fewer types of bacteria were found in the group with low $\mathrm{pH}$; these consisted mainly of staphylococci, which were found in all of the patients, and streptococci (Table 1).

A similar pattern of colonisation was found when analysing the microbial flora of only the gastric juice of these patients (Table 2), although micrococci and veillonella were not always detected in the juice in patients with hypogammaglobulinaemia despite their presence in the gastric mucosa (Tables 3, 4, and 5). When present, streptococci tended to be the dominant organism (Table 2), although bifidobac- teria and haemophili attained high concentrations in one of the patients with hypogammaglobulinaemia (Table 2). In general, from a combined qualitative and quantitative aspect, the patients with pernicious anaemia had the most complex gastric juice flora. As expected, the group with low $\mathrm{pH}$ had a much simpler flora and harboured much lower concentrations of these bacteria (Table 2).

Tables 3, 4, and 5 show the types of bacteria found in association with the gastric mucosa of the antrum body and fundus. Within any one group the patients with hypogammaglobulinaemia and those with per-

Table 3 Micro-organisms associated with gastric mucosa of antrum (figures are numbers of patients and mean log ${ }_{10}$ No of organisms/g tissue)

\begin{tabular}{|c|c|c|c|}
\hline Micro-organism & $\begin{array}{l}\text { Patients with hypogammaglobulinaemia } \\
(n=6)\end{array}$ & $\begin{array}{l}\text { Patients with pernicious anaemia } \\
(n=7)\end{array}$ & $\begin{array}{l}\text { Group with low pH } \\
(n=5)\end{array}$ \\
\hline $\begin{array}{l}\text { Gram positive cocci: } \\
\text { Aerobic streptococci } \\
\text { Anaerobic streptococci } \\
\text { Micrococci } \\
\text { Staphylococci }\end{array}$ & $\begin{array}{l}6(5 \cdot 6) \\
0 \\
3(4 \cdot 6) \\
3(4 \cdot 4)\end{array}$ & $\begin{array}{l}7(5 \cdot 7) \\
1(3 \cdot 4) \\
5(4 \cdot 3) \\
2(4 \cdot 0)\end{array}$ & $\begin{array}{l}0 \\
0 \\
0 \\
2(3 \cdot 8)\end{array}$ \\
\hline $\begin{array}{l}\text { Gram negative cocci: } \\
\text { Neisseria } \\
\text { Veillonella }\end{array}$ & $\begin{array}{l}1(6 \cdot 1) \\
3(5 \cdot 1)\end{array}$ & $\begin{array}{l}1(4 \cdot 4) \\
6(4 \cdot 2)\end{array}$ & $\begin{array}{l}0 \\
0\end{array}$ \\
\hline $\begin{array}{l}\text { Gram positive rods: } \\
\text { Lactobacilli } \\
\text { Diptheroides } \\
\text { Bifidobacteria } \\
\text { Eubacteria }\end{array}$ & $\begin{array}{l}1(3 \cdot 3) \\
1(5 \cdot 4) \\
2(7 \cdot 0) \\
1(4 \cdot 2)\end{array}$ & $\begin{array}{l}1(4 \cdot 1) \\
3(4 \cdot 0) \\
5(4 \cdot 1) \\
1(3 \cdot 6)\end{array}$ & $\begin{array}{l}0 \\
0 \\
0 \\
0\end{array}$ \\
\hline $\begin{array}{l}\text { Gram negative rods: } \\
\text { Haemophilus } \\
\text { Bacteroides } \\
\text { Proteus } \\
\text { Hafnia }\end{array}$ & $\begin{array}{l}1(5 \cdot 7) \\
2(5 \cdot 5) \\
1(4 \cdot 0) \\
1(4 \cdot 6)\end{array}$ & $\begin{array}{l}1(3 \cdot 6) \\
0 \\
0 \\
0\end{array}$ & $\begin{array}{l}0 \\
0 \\
0 \\
0\end{array}$ \\
\hline
\end{tabular}


Table 4 Micro-organisms associated with gastric mucosa of stomach body (figures are numbers of patients and mean $\log _{10}$ No of organisms/g tissue)

\begin{tabular}{|c|c|c|c|}
\hline Micro-organism & $\begin{array}{l}\text { Patients with hypogammaglobulinaemia } \\
(n=6)\end{array}$ & $\begin{array}{l}\text { Patients with pernicious anaemia } \\
(n=7)\end{array}$ & $\begin{array}{l}\text { Group with low pH } \\
(n=5)\end{array}$ \\
\hline $\begin{array}{l}\text { Gram positive cocci: } \\
\text { Aerobic streptococci } \\
\text { Micrococci } \\
\text { Staphylococci }\end{array}$ & $\begin{array}{l}6(5 \cdot 9) \\
5(4 \cdot 6) \\
2(4 \cdot 4)\end{array}$ & $\begin{array}{l}7(6 \cdot 5) \\
5(4 \cdot 6) \\
2(5 \cdot 2)\end{array}$ & $\begin{array}{l}3(4 \cdot 2) \\
1(4 \cdot 0) \\
2(3 \cdot 8)\end{array}$ \\
\hline $\begin{array}{l}\text { Gram negative cocci: } \\
\text { Neisseria } \\
\text { Veillonella }\end{array}$ & $\begin{array}{l}1(5 \cdot 5) \\
4(4 \cdot 7)\end{array}$ & $\begin{array}{l}1(4 \cdot 7) \\
6(4 \cdot 9)\end{array}$ & $\begin{array}{l}0 \\
0\end{array}$ \\
\hline $\begin{array}{l}\text { Gram positive rods: } \\
\text { Lactobacilli } \\
\text { Diptheroides } \\
\text { Bifidobacteria } \\
\text { Propionibacteria } \\
\text { Gram negative rods: }\end{array}$ & $\begin{array}{l}1(4 \cdot 6) \\
0 \\
1(2 \cdot 7) \\
0\end{array}$ & $\begin{array}{l}3(3 \cdot 8) \\
3(4 \cdot 4) \\
5(4 \cdot 2) \\
1(6 \cdot 0)\end{array}$ & $\begin{array}{l}1(4 \cdot 6) \\
0 \\
1(3 \cdot 6) \\
1(4 \cdot 0)\end{array}$ \\
\hline $\begin{array}{l}\text { Haemophilus } \\
\text { Bacteroides } \\
\text { Hafnia }\end{array}$ & $\begin{array}{l}1(5 \cdot 3) \\
1(4 \cdot 4) \\
1(4 \cdot 1)\end{array}$ & $\begin{array}{l}0 \\
0 \\
0\end{array}$ & $\begin{array}{l}0 \\
0 \\
0\end{array}$ \\
\hline
\end{tabular}

nicious anaemia were colonised as commonly at the antrum as at the body and fundus, whereas the group with low $\mathrm{pH}$ had a more complex flora localised in the body of the stomach rather than the antrum and fundus. In keeping with the findings in gastric juice, the bacteria most commonly associated with the gastric mucosa in all three groups were streptococci, micrococci, staphylococci, and veillonellae. Interestingly, klebsiella, though present in the gastric juice of five of the patients with pernicious anaemia, were not associated with the gastric mucosa. Overall, however, the flora associated with the mucosa did not differ significantly from that of the gastric juice.

\section{GASTRIC JUICE ENZYMES}

Table 6 shows the results. All the gastric juices tested contained phosphoamidase activity, and none of them contained chymotrypsin, $\alpha$ galactosidase, or $\alpha$ mannosidase. All the juices tested from the patients with hypogammaglobulinaemia and pernicious anaemia contained alkaline and acid phosphatase, $C_{4}$ and $C_{8}$ esterase, and $C_{8}$ esterase lipase. The only enzymatic activity noted in the group with low $\mathrm{pH}$ was phosphoamidase and $\mathrm{C}_{4}$ and $\mathrm{C}_{8}$ esterase. The presence of $\beta$ glucuronidase and $C_{14}$ lipase, which was present in the same three patients with hypogammaglobulinaemia, seemed to differentiate this group of patients from the others.

\section{GASTRIC JUICE AMINES, ETHANOL, AND FATTY ACIDS}

Table 7 shows the results for gastric juice amines and ethanol, with the corresponding $\mathrm{pH}$ values of gastric juice and degree of bacterial colonisation. Short chain fatty acids were not detected in any of the samples analysed, and the only alcohol detected was ethanol. Neither of the phenolics, p-cresol or

Table 5 Micro-organisms associated with gastric mucosa of fundus (figures are numbers of patients and mean $\log _{10}$ No of organisms/g tissue)

\begin{tabular}{|c|c|c|c|}
\hline Micro-organism & $\begin{array}{l}\text { Patients with hypogammaglobulinaemia } \\
(n=6)\end{array}$ & $\begin{array}{l}\text { Patients with pernicious anaemia } \\
(n=7)\end{array}$ & $\begin{array}{l}\text { Group with low pH } \\
(n=5)\end{array}$ \\
\hline $\begin{array}{l}\text { Gram positive cocci: } \\
\text { Aerobic streptococci } \\
\text { Anaerobic streptococci } \\
\text { Micrococci } \\
\text { Staphylococci }\end{array}$ & $\begin{array}{l}6(6 \cdot 0) \\
0 \\
3(4 \cdot 9) \\
2(6 \cdot 4)\end{array}$ & $\begin{array}{l}7(6 \cdot 0) \\
1(4 \cdot 1) \\
6(4 \cdot 6) \\
3(4 \cdot 2)\end{array}$ & $\begin{array}{l}1(5 \cdot 2) \\
0 \\
0 \\
0\end{array}$ \\
\hline $\begin{array}{l}\text { Gram negative cocci: } \\
\text { Neisseria } \\
\text { Veillonella }\end{array}$ & $\begin{array}{l}1(5 \cdot 0) \\
5(4 \cdot 7)\end{array}$ & $\begin{array}{l}0 \\
5(4 \cdot 5)\end{array}$ & $\begin{array}{l}0 \\
0\end{array}$ \\
\hline $\begin{array}{l}\text { Gram positive rods: } \\
\text { Lactobacilli } \\
\text { Diptheroides } \\
\text { Bifidobacteria } \\
\text { Propionibacteria }\end{array}$ & $\begin{array}{l}0 \\
1(5 \cdot 2) \\
3(5 \cdot 2) \\
1(3 \cdot 6)\end{array}$ & $\begin{array}{l}3(3 \cdot 8) \\
1(3 \cdot 5) \\
6(5 \cdot 3) \\
0\end{array}$ & $\begin{array}{l}0 \\
1(3 \cdot 3) \\
0 \\
0\end{array}$ \\
\hline $\begin{array}{l}\text { Gram negative rods: } \\
\text { Haemophilus } \\
\text { Bacteroides } \\
\text { Hafnia }\end{array}$ & $\begin{array}{l}1(4 \cdot 2) \\
1(4 \cdot 1) \\
1(3 \cdot 5)\end{array}$ & $\begin{array}{l}0 \\
0 \\
0\end{array}$ & $\begin{array}{l}0 \\
0 \\
0 \\
0\end{array}$ \\
\hline
\end{tabular}


Table 6 Enzymatic activity present in gastric juice (figures are numbers of patients)

\begin{tabular}{|c|c|c|c|}
\hline Enzyme & $\begin{array}{l}\text { Patients with hypogammaglobulinaemia } \\
(n=4)\end{array}$ & $\begin{array}{l}\text { Patients with pernicious anaemia } \\
(n=5)\end{array}$ & $\begin{array}{l}\text { Group with low } p H \\
(n=4)\end{array}$ \\
\hline $\begin{array}{l}\text { Alkaline and acid phosphatase } \\
\mathrm{C}_{4} \text { and } \mathrm{C}_{8} \text { esterase } \\
\mathrm{C}_{14} \text { lipase } \\
\mathrm{C}_{8} \text { esterase lipase } \\
\text { Leucine arylamidase } \\
\text { Valine arylamidase } \\
\text { Cystine arylamidase } \\
\text { Trypsin }\end{array}$ & $\begin{array}{l}4 \\
4 \\
3 \\
4 \\
2 \\
2 \\
1 \\
2\end{array}$ & $\begin{array}{l}5 \\
5 \\
1 \\
5 \\
5 \\
1 \\
1 \\
1\end{array}$ & $\begin{array}{l}0 \\
2 \\
0 \\
0 \\
0 \\
0 \\
0 \\
0\end{array}$ \\
\hline $\begin{array}{l}\text { Chymotrypsin, } \alpha \text { galactosidase } \\
\text { and } \alpha \text { mannosidase } \\
\beta \text { Galactosidase and }\end{array}$ & 0 & 0 & 0 \\
\hline $\begin{array}{l}\beta \text { Glucosidase } \\
\beta \text { Glucuronidase } \\
\alpha \text { Glucosidase } \\
N \text { acetyl- } \beta \text {-glucosaminidase } \\
\alpha \text { Fucosidase } \\
\text { Phosphoamidase } \\
\text { Mean pH of juice } \\
\text { Mean } \log _{10} \text { No of bacteria/ml juice }\end{array}$ & $\begin{array}{l}1 \\
3 \\
3 \\
3 \\
0 \\
4 \\
8 \cdot 1 \\
5 \cdot 8\end{array}$ & $\begin{array}{l}0 \\
0 \\
4 \\
2 \\
1 \\
5 \\
7 \cdot 3 \\
6 \cdot 6\end{array}$ & $\begin{array}{c}0 \\
0 \\
0 \\
0 \\
0 \\
4 \\
1 \cdot 6 \\
<3 \cdot 0\end{array}$ \\
\hline
\end{tabular}

phenol, which would normally have been detected under these conditions, was found. The only amines detected were dimethylamine and trimethylamine, despite the fact that it was possible to detect readily standard solutions of all the straight chain amines up to amylamine at concentrations of $10 \mu \mathrm{g} / \mathrm{ml}$. Although standards for the cyclic secondary amines were not run, it should have been possible to detect piperidine and pyrrolidine, though neither was found.

There was little difference in the concentrations of dimethylamine present in the three groups of patients. There was a difference, however, in the trimethylamine content, with the concentrations in the patients with hypogammaglobulinaemia significantly higher than those in the comparison group with low $\mathrm{pH}(\mathrm{p}=0.01)$.

An extensive range of ethanol concentrations was found in the patients (Table 7). In two of the patients with pernicious anaemia and one of the patients with low $\mathrm{pH}$ ethanol was not detected. The concentrations in the patients with hypogammaglobulinaemia were significantly higher than those in the patients with pernicious anaemia $(p=0.02)$.

There was no direct correlation between the $\mathrm{pH}$ of gastric juice or the degree of colonisation with ethanol concentrations.

\section{Discussion}

Intragastric $\mathrm{pH}$ is the principal determinant of gastric flora, and in patients with a high gastric $\mathrm{pH}$ there is a corresponding increase in microbial colonisation. $^{23}$ Interestingly, the degree of colonisation in patients with achlorhydria and hypogammaglobulinaemia was not as great as that in those with typical pernicious anaemia. Possibly, the higher $\mathrm{pH}$ values and the higher concentrations of nitrite' in these patients with hypogammaglobulinaemia partially inhibited microbial growth. In keeping with previous reports, we found that the predominant flora of the achlorhydric stomach consisted mostly of Gram positive facultative cocci and that the most common anaerobe was veillonella. Our detailed analysis, however, showed that a greater variety of bacteria were present than previously reported. There was also a rich flora associated with the mucosal lining of the antrum, body, and fundus of the stomach. We could find only one other report on the gastric mucosal flora ${ }^{20}$ : in this study organisms had failed to grow from gastric biopsies in four of

Table 7 Metabolic profile of gastric aspirates. Values are means (SD) (and ranges)

\begin{tabular}{|c|c|c|c|c|c|}
\hline Subjects & Dimethylamine ( $\mu \mathrm{g} / \mathrm{ml})$ & Trimethylamine ( $\mu \mathrm{g} / \mathrm{ml})$ & Ethanol (mmolll)* & $p H$ & $\begin{array}{l}\text { Mean } \log _{10} \text { No of } \\
\text { organisms/ml }\end{array}$ \\
\hline $\begin{array}{l}\text { Pernicious anaemia }(n=4) \\
\text { Hypogammaglobulinaemia } \\
(n=4) \\
\text { Group with low } \mathrm{pH}(\mathrm{n}=5)\end{array}$ & $\begin{array}{l}9 \cdot 8(3 \cdot 5) \\
(6-15 \cdot 4) \\
13 \cdot 4(8 \cdot 5) \\
(2 \cdot 5-22 \cdot 3) \\
11 \cdot 8(6 \cdot 6) \\
(5 \cdot 4-22 \cdot 2)\end{array}$ & $\begin{array}{l}21 \cdot 2(16 \cdot 3) \\
(0-38) \\
16 \cdot 5(13 \cdot 6) \\
(3 \cdot 6-40 \cdot 3) \\
0 \cdot 9(1 \cdot 0) \\
(0-2 \cdot 1)\end{array}$ & $\begin{array}{l}0.8(1 \cdot 1) \\
(0-2 \cdot 6) \\
18 \cdot 7(6 \cdot 7) \\
(11 \cdot 3-26 \cdot 5) \\
7 \cdot 5(4 \cdot 8) \\
(0-13 \cdot 5)\end{array}$ & $\begin{array}{l}7 \cdot 3(0.3) \\
(6 \cdot 8-7 \cdot 5) \\
8 \cdot 1(0.2) \\
(7 \cdot 8-8 \cdot 3) \\
1 \cdot 9(0.7) \\
(1 \cdot 3-3 \cdot 4)\end{array}$ & $\begin{array}{l}6 \cdot 6 \\
(5 \cdot 6-7 \cdot 6) \\
6 \cdot 2 \\
(4 \cdot 8-7 \cdot 3) \\
<3 \cdot 0 \\
(<3 \cdot 0-3 \cdot 4)\end{array}$ \\
\hline
\end{tabular}

*SI conversion to traditional units: $1 \mathrm{mmol} / \mathrm{l} \approx 4.7 \mathrm{mg} / 100 \mathrm{ml}$. 
seven patients who underwent endoscopy for suspected carcinoma. The three positive samples were from patients with confirmed gastric cancer.

There was little overall difference in the gastric flora between different sites in the stomach in either patients with hypogammaglobulinaemia or those with pernicious anaemia. This suggests that the degree of gastric atrophy has little influence on the attachment of bacteria to mucosa, as most of the patients with hypogammaglobulinaemia had a pangastritis affecting the antrum, unlike most of those with pernicious anaemia in whom the antral mucosa was normal. ${ }^{21}$

Despite the attention that the theory that nitrosamines and gastric cancer are related has received, most of the work has concentrated on the presence of bacteria that reduce nitrate ${ }^{1579}$ and the concentrations of nitrites in gastric juice..$^{7-9}$ Most workers have assumed that amines from foodstuffs ${ }^{22-24}$ would be present, and this has been confirmed by the indirect finding of nitrosatable amines ${ }^{8}$ and the direct finding of $N$ nitrosamines ${ }^{25}$ in gastric juice. We directly screened for, identified, and quantified some of the amines present. Of straight chain amines up to $\mathrm{C}_{6}$, only dimethylamine and trimethylamine were found. All three groups of patients had similar concentrations of dimethylamine, and it is therefore unlikely that the dimethylamine was the product of microbial metabolism in the stomach. The most likely source of this amine is the diet. In contrast, the concentration of trimethylamine, which reacts only poorly with nitrite, was higher in the patients with hypogammaglobulinaemia and pernicious anaemia than in those with dyspepsia. We are unable to explain this finding.

Although all of the ingredients required for the production of nitrosamines are present in the achlorhydric stomachs of these patients-that is, bacteria that reduce nitrate, nitrite, and nitrosatable amines - the procarcinogenic nitrosamines require metabolic activation to exert their carcinogenic effect. It has been shown that explant cultures of human colonic cells can metabolise dimethylnitrosamine to the active carcinogen ${ }^{26}$ and gastric cells would probably be equally active. An alternative method of this activating nitrosamine would be a microbial mediated nitroso group exchange between an amide and a nitrosamine to form a highly reactive nitrosamide. This has been shown in vitro for various amides, dimethylnitrosamine, and $E$ coli. ${ }^{27}$ Although we did not measure the concentrations of $N$ nitroso compounds in gastric juice in this study, concentrations of about $0.5 \mu \mathrm{M} / \mathrm{kg}$ have been found in the gastric juice of two patients with achlorhydria and hypogammaglobulinaemia (Smith and Webster, unpublished findings).

The gastric juices were also analysed for microbial metabolites and gastric juice enzymes in an attempt to find markers that could differentiate states of disease. A surprising finding was the presence of ethanol in the gastric juice of these subjects. No exogenous source for this ethanol could be found; the patients had not been drinking, and it was assumed that its presence was the result of microbial activity. A similar finding and conclusion were reached by others who detected ethanol in the stomachs of patients taking antacids or cimetadine..$^{28}$ We found no correlation, however, between concentrations of ethanol and the degree of microbial colonisation, the presence or absence of yeasts, or the $\mathrm{pH}$ of gastric juice. The most striking finding was the low concentrations of ethanol found in the patients with pernicious anaemia compared with the two other groups. The patients with hypogammaglobulinaemia had particularly high concentrations. Alcohol may have a role in the aetiology of oesophageal cancer as it facilitates the penetration of nitrosamines into mucosa ${ }^{24}$ and a similar situation may occur in the stomach.

The total activity of various enzymes in gastric juices such as lactic dehydrogenase and $\beta$ glucuronidase $^{30}$ is raised in gastric cancer. Possibly, enzymes derived from microbes, such as $\beta$ glucuronidase, could contribute to these changes. We found a wide range of enzymatic activity in the gastric juices of the patients with achlorhydria and lesser activity in the group with normal acid $\mathrm{pH}$ dyspepsia. In view of the findings of an association between high levels of $\beta$ glucuronidase and gastric cancer, it is interesting that this enzyme seemed to differentiate the patients with hypogammaglobulinaemia, who have a high risk of gastric cancer, from the other patients. ${ }^{31}$ These raised enzyme activities, however, may merely reflect the greater extent of gastritis in these patients. ${ }^{21}$ An additional differentiating marker, $\mathrm{C}_{14}$ lipase, was also higher in the patients with hypogammaglobulinaemia, and it may prove worth while to include this enzyme in any further studies on the value of screening gastric juice enzymes in gastric cancer.

In conclusion, this study shows that there is a complex microbial flora in the gastric juice and associated with the gastric mucosa of the achlorhydric stomach. The metabolic potential of this flora is high, and several possible microbial metabolites and enzymes were detected. There is no evidence, however, that these bacteria are responsible for producing carcinogens or for the much higher incidence of gastric carcinoma in patients with hypogammaglobulinaemia compared with those suf- 
fering from typical pernicious anaemia. The particularly high concentrations of ethanol in these patients remains unexplained, and further investigation into their origin might uncover further differences in the gastric environment between patients deficient in antibodies and those with typical pernicious anaemia.

\section{References}

' Dolby JM, Webster ADB, Borriello SP, Barclay FE, Bartholomew BA, Hill MJ. Bacterial colonization and nitrite concentrations in the achlorhydric stomachs of patients with primary hypogammaglobulinaemia or classical pernicious anaemia. Scand J Gastroenterol 1984; 19: 105-10.

${ }^{2}$ Drasar BS. Shiner M, McLeod GM. Studies on the intestinal flora. 1. The bacteria of the gastrointestinal tract in healthy and achlorhydric persons. Gastroenterology 1969;56:71-9.

${ }^{3}$ Gray JDA, Shiner M. Influence of gastric $\mathrm{pH}$ on gastric and jejunal flora. Gut 1967;8:574-81.

${ }^{4}$ Hillman KM, Riordan T, O Farrell SM. Tabaqchali S. Colonization of the gastric contents in critically ill patients. Crit Care Med 1982; 10:444-7.

s Ruddell WSJ, Axon ATR, Findlay JM, Bartholomew BA, Hill MJ. Effect of cimetidine on the gastric bacterial flora. Lancet 1980; i:672-4.

- Snepar R, Poporad GA, Romano JM, Kobasa WD, Kaye D. Effect of cimetidine and antacid on gastric microbial flora. Infect Immun 1982;36:518-24.

7 Stockbrugger RW, Cotton PB, Eugenides N, Bartholomew BA, Hill MJ, Walters CL. Intragastric nitrites, nitrosamines, and bacterial overgrowth during cimetidine treatment. Gut 1982; 23: 1048-54.

${ }^{8}$ Ruddell WSJ, Bone ES, Hill MJ, Walters CL. Pathogenesis of gastric cancer in pernicious anaemia. Lancet 1978;i:521-3.

" Ruddell WSJ, Bone ES, Hill MJ, Blendis LM, Walters CL. Gastric-juice nitrite. A risk factor for cancer in the hypochlorhydric stomach? Lancet 1976;ii: 1037-9.

${ }^{10}$ Crowther JS. Transport and storage of faeces for bacteriological examination. J Appl Bacteriol 1971;34:477-83.

" Borriello SP, Hudson MJ, Hill MJ. Investigations of the gastrointestinal bacterial flora. Clin Gastroenterol 1978;7:329-49.

${ }_{12}$ Miles AA, Misra SS. The estimation of the bactericidal power of the blood. J Hyg 1938;38:732-49.

${ }^{13}$ Rogosa M, Mitchell JA, Wiseman RF. A selective medium for the isolation of oral and fecal lactobacilli. $J$ Bacteriol 1951;62:132-3.

14 Donnelly LS, Hartman PA. Gentamycin-based medium for the isolation of group D streptococci and application of the medium to water analysis. Applied and Environmental Microbiology 1978;35:576-81. is Koransky JR, Allen SD, Dowell VR. Use of ethanol for selective isolation of sporeforming microorganisms. Applied and Environmental Microbiology 1978;35:762-5.

${ }^{16}$ Willis AT, Hobbs G. Some new media for the isolation and identification of clostridia. Journal of Pathology and Bacteriology 1959;77:511-21.

${ }^{17}$ Holdeman LV, Cato EP, Moore WEC. Anaerobe laboratory manual. 4th ed. Blacksburg: Virginia Polytechnic Institute, 1977.

${ }^{18}$ Barrett E, Lynam G, Trustey S. Gas liquid chromatography for detection of bacteriuria: examination for volatile acidic and neutral compounds. J Clin Pathol 1978;31:859-65.

${ }^{19}$ Hill ID, Peto R. Probabilities derived from finite populations. Applied Statistics 1971;20:99-105.

${ }^{20}$ Nelson DP, Mata LJ. Bacterial flora associated with the human gastrointestinal mucosa. Gastroenterology 1970;58:56-61.

${ }^{21}$ Webster ADB. Immune deficiency disorders and the gastrointestinal tract. In: Triger DR, ed. Clinical immunology of the liver and gastrointestinal tract. Bristol, John Wright and Sons (in press).

${ }^{22}$ Kawamura T, Sakai K, Miyazawa F, Wada H, Ito Y, Tanimura A. Distribution of seconday amines in food. Journal of the Food Hygienic Society of Japan 1971;12:192-7.

${ }^{23}$ Kawamura T, Sakai K, Miyazawa F, Wada H, Ito Y, Tanimura A. Distribution of seconday amines in food (2). Journal of the Food Hygienic Society of Japan 1971;12:394-8.

${ }^{24}$ Ayukawa I, Sakai A, Tanimura A. Relation of alkalinity to recovery in the determination of secondary amines. Journal of the Food Hygienic Society of Japan 1973;14:100-4.

${ }^{25}$ Reed PL, Smith PLR, Haines K, House FR, Walters CL. Gastric juice $\mathrm{N}$-nitrosamine in health and gastroduodenal disease. Lancet 1982; ii:550-2.

${ }^{26}$ Autrup H, Harris CC, Trump BF. Metabolism of acyclic and cyclic $\mathrm{N}$-nitrosamines by cultured human colon (40294). Proc Soc Exp Biol Med 1978;159:111-5.

${ }^{27}$ Mandel M, Ichinotsubo D, Mower $\mathrm{H}$. Nitroso group exchange as a way of activation of nitrosamines by bacteria. Nature 1977; 267:248-9.

${ }^{28}$ Bode JC, Rust S, Bode C. The effect of cimetidine treatment on ethanol formation in the human stomach. Scand J Gastroenterol 1984; 19:853-6.

${ }^{29}$ Tuyns AJ, Gricuite LL. Carcinogenic substances in alcoholic beverages. Excerpta Medica International Congress Series 1980;484:130-5.

${ }^{30}$ Rogers K, Roberts GM, Williams GT. Gastric-juice enzymesan aid in the diagnosis of gastric cancer? Lancet 1980;i:1124 6.

${ }^{31}$ Kinlen LJ, Webster ADB, Bird AG, et al. Prospective study of cancer in patients with hypogammaglobulinaemia. Lancet $1985 ; \mathrm{i}: 263-6$

Requests for reprints to: Dr SP Borriello, Division of Communicable Diseases, Clinical Research Centre, Watford Road, Harrow, Middlesex, HA1 3UJ, England. 